\title{
An Efficient Route to Unsymmetrical Bis(azolium) Salts: CCC-NHC Pincer Ligand Complex
}

\section{Precursors}

Hannah K. Box, Tyler O. Howell, William E. Kennon, Griffin A. Burk, Henry U. Valle, T. Keith Hollis*

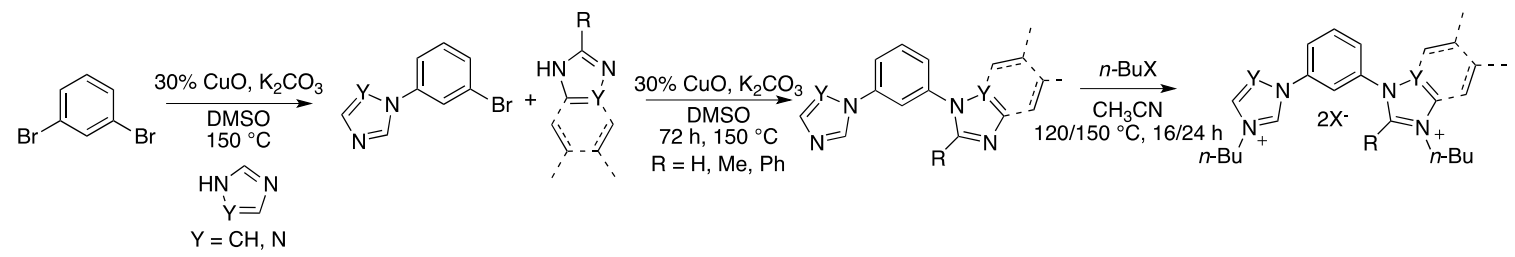

\section{Abstract}

The coupling of $\mathrm{N}$-heterocyclic azoles (imidazoles, benzimidazoles, triazoles) to bromobenzenes (1,2-; 1,3-; or 1,4) in a step-wise, sequential manner was accomplished by manipulation of reaction time and stoichiometry, which provided straight-forward access to unsymmetrical bis(azolium) salts in only three isolation steps from commercially-available starting materials. Eight mono(azole) substituted bromobenzenes, four mono(azolium)bromobenzene salts, twelve unsymmetrical bis(azole)benzenes, and fourteen unsymmetrical bis(azolium) salts, which are precursors for pincer ligand complexes, are reported.

\section{Introduction}

Heterocycles are of immense importance biologically and industrially. The pharmaceutical industry has exploited this characteristic to the point where more than $90 \%$ of 
new drugs contain a heterocycle. ${ }^{1}$ Two important five-membered nitrogen heterocycles are imidazole and triazole (azoles).

Azolium salts have found widespread use as ionic liquids ${ }^{2}$ and have shown biological activity including antitumor, ${ }^{3}$ antibacterial, ${ }^{4}$ antimicrobial activities, ${ }^{5}$ and interaction with DNA. ${ }^{6}$ They have been used in the design of GalTs inhibitors, ${ }^{7}$ anion receptors, ${ }^{8}$ OLED materials, ${ }^{9}$ and as ligand precursors for transition metal complexes, which commonly feature improved stability, catalytic reactivity, and selectivity. ${ }^{10}$<smiles>[R]Cc1c(Cc2ccccc2)c(C)n(Cc2ccccc2)c1C</smiles><smiles></smiles><smiles></smiles>
$\mathrm{R}=$ alkyl

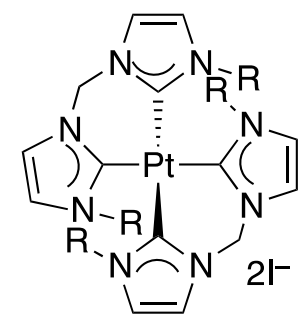

$$
\mathrm{R}=\mathrm{Me}, \mathrm{iPr}, \mathrm{nBu}, \mathrm{cy}
$$

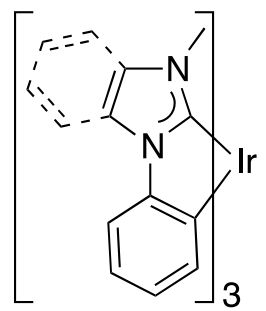

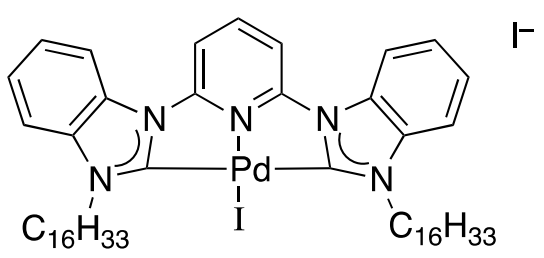

Figure 1. Examples of azolium or azolylidene complexes in biological and materials applications

Carbenes have a long history as reactive intermediates in organic chemistry, ${ }^{11}$ and over the last two decades many stable carbenes have been isolated ${ }^{11-12}$ and characterized, which has provided chemists with new reagents. ${ }^{13}$ The many variants of $\mathrm{N}$-heterocyclic carbenes (NHCs), the most popular and widely applied version, have become common as ligands coordinated to transition metals in the field of organometallic chemistry. Because of their strong $\sigma$-donating ability, limited dissociation, and neutral charge, NHCs have exceeded phosphine ligands as a means of generating more durable catalysts. As the synthetic utility of NHCs has developed; 
research has expanded from the typical imidazolium-derived NHCs to include triazole, abnormal NHC (aNHC) ligands (C4 or C5 bound), acyclic and numerous other examples. ${ }^{14}$ Further investigations, experimental and theoretical, have found $a \mathrm{NHC}$ ligands to be stronger donors and in some cases their complexes were found to have greater reactivity than their $\mathrm{C}-2$ coordinated equivalents. ${ }^{14 c}$

While pincer ligands have found widespread use due to the ease of varying the lateral donor groups, which provides an effective way to alter the properties of the chelated metal center, the development of pincer ligand complexes featuring $\mathrm{NHC}$ moieties has suffered from a lack of synthetic methodologies allowing for new and diverse architectures. In 2012 while attempting to synthesize a normal CCC-NHC pincer complex, Braunstein reported that among a mixture of products a pincer complex was isolated containing one "normally-coordinated" NHC and one "abnormally-coordinated" $\mathrm{NHC}^{15}$ We had begun development of an approach to prepare unsymmetrical complexes strategically. The previously reported efficient one pot synthesis of 1,3-bis(azole)benzenes employing a CuO-catalyzed aryl amination reaction of 1,3dibromobenzene followed by alkylation yielding symmetrical bis(azolium) salts provided symmetrical CCC-NHC ligand precursors for the generation of transition metal complexes. ${ }^{16}$ Previously reported synthetic methodologies for the preparation of NHC pincer ligand precursors does not directly allow for the expansion of architectural diversity, thus making a methodology for the direct, efficient synthesis of unsymmetrical bis(azolium) salts a necessity. Reported herein a synthetic methodology for preparing unsymmetrical salts. This methodology allows for the architectural diversity of compounds featuring unsymmetrical diazoles to be expanded and may prove useful in the synthesis of a variety of compounds for a diverse array of applications. 


\section{Results and Discussion}

Synthesis of the unsymmetrical bis(azolium) salts began by reacting imidazole (2), 2-

methylimidazole (3), 2-phenylimidazole (4), 1,2,4-triazole (5), benzimidazole (6), or 5,6dimethylbenzimidazole (7) with dibromobenzene (1) to generate mono-azole arenes 8 - 15 (Scheme 1). While after $24 \mathrm{~h}$ no starting material was present in the synthesis of 8-9 and 11-15, the sterically congested 2-phenylimidazole derivative, $\mathbf{1 0}$, required a longer reaction time of 72 h. Monitoring the preparation of $\mathbf{9}$ via thin layer chromatography (TLC) provided further insight into the rate of conversion. The formation of 1,3-bis(2-methylimidazole)benzene was found to become competitive with the formation of the mono-product 9 after $24 \mathrm{~h}$. This information aided in the acquisition of higher yields of the remaining compounds. All future syntheses of mono(azole) substituted benzenes were worked up before product competition began. There was a clear trend showing the effect of steric congestion at the imidazole C -2 position on yield $(8>9>10)$. A decrease in yield was noted when comparing an unsubstituted imidazole (8) to benzimidazole derivatives (12 and $\mathbf{1 3}$ ). Due to potential biological investigations, the methodology was extended to include examples of 1,2- and 1,4-substituted arenes. 
Scheme 1. Synthesis of mono(azole)benzenes

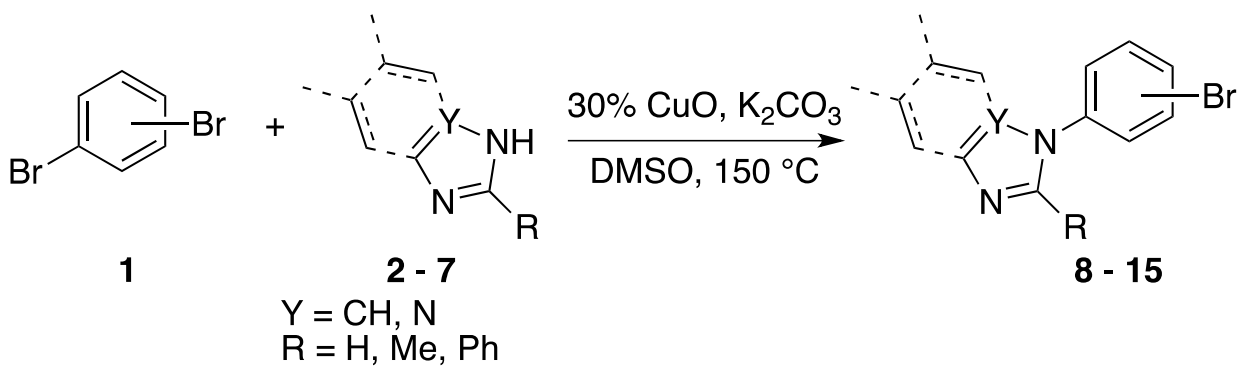<smiles>Brc1cccc(-n2ccnc2)c1</smiles>

8

24 h, $79 \%$<smiles>Brc1cccc(-n2cnc3ccccc32)c1</smiles>

24 h, 35\%<smiles>Cc1nccn1-c1cccc(Br)c1</smiles>

9

24 h, $68 \%$<smiles>Cc1cc2ncn(-c3cccc(Br)c3)c2cc1C</smiles>

24 h, 34\%<smiles>Brc1cccc(-n2ccnc2-c2ccccc2)c1</smiles>

72 h, $47 \%$<smiles>Brc1ccccc1-n1ccnc1</smiles>

24 h, 38\%<smiles>Brc1cccc(-n2cncn2)c1</smiles>

11

24 h, $61 \%$ 
Scheme 2. Alkylation of select mono(azole)benzenes.
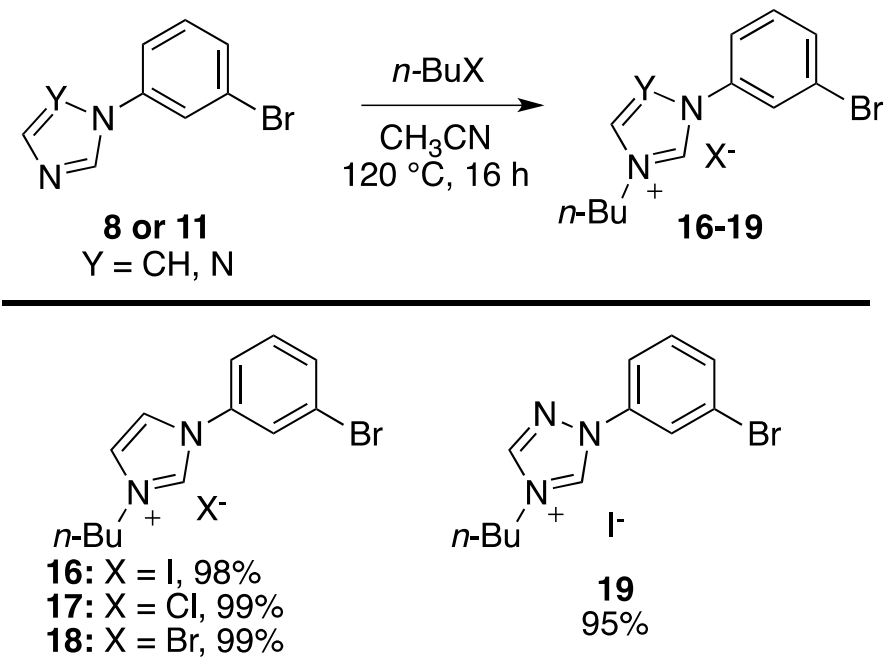

Subsequent reactions for the synthesis of unsymmetrical bis(azole)benzenes were conducted primarily with $\mathbf{8}$ or $\mathbf{1 1}$ with a triazole, benzimidazole, or imidazole (Scheme 3 ). All products were obtained in moderate to good yield on a multigram scale. As in the mono(azole) substituted benzene case, there was a similar trend in yield as seen between the substitution patterns $(1,4>1,3>1,2)$. The reaction of $\mathbf{8}$ and $\mathbf{1 1}$ with imidazole derivatives substituted at the $\mathrm{C}-\mathbf{2}$ position yielded compounds featuring a potential for mixed $\mathrm{NHC} / a \mathrm{NHC}$ ligand $(\mathbf{2 0}, \mathbf{2 1}, \mathbf{2 5}$, $\mathbf{2 6}, \mathbf{2 7})$, when bound to a metal. Many of the compounds $(\mathbf{2 2}, \mathbf{2 5 - 3 1 )}$ feature a 1,2,4-triazole as one lateral donor group, providing potentially diverse donor properties. 
Scheme 3. Synthesis of unsymmetrical bis(azole)benzenes.
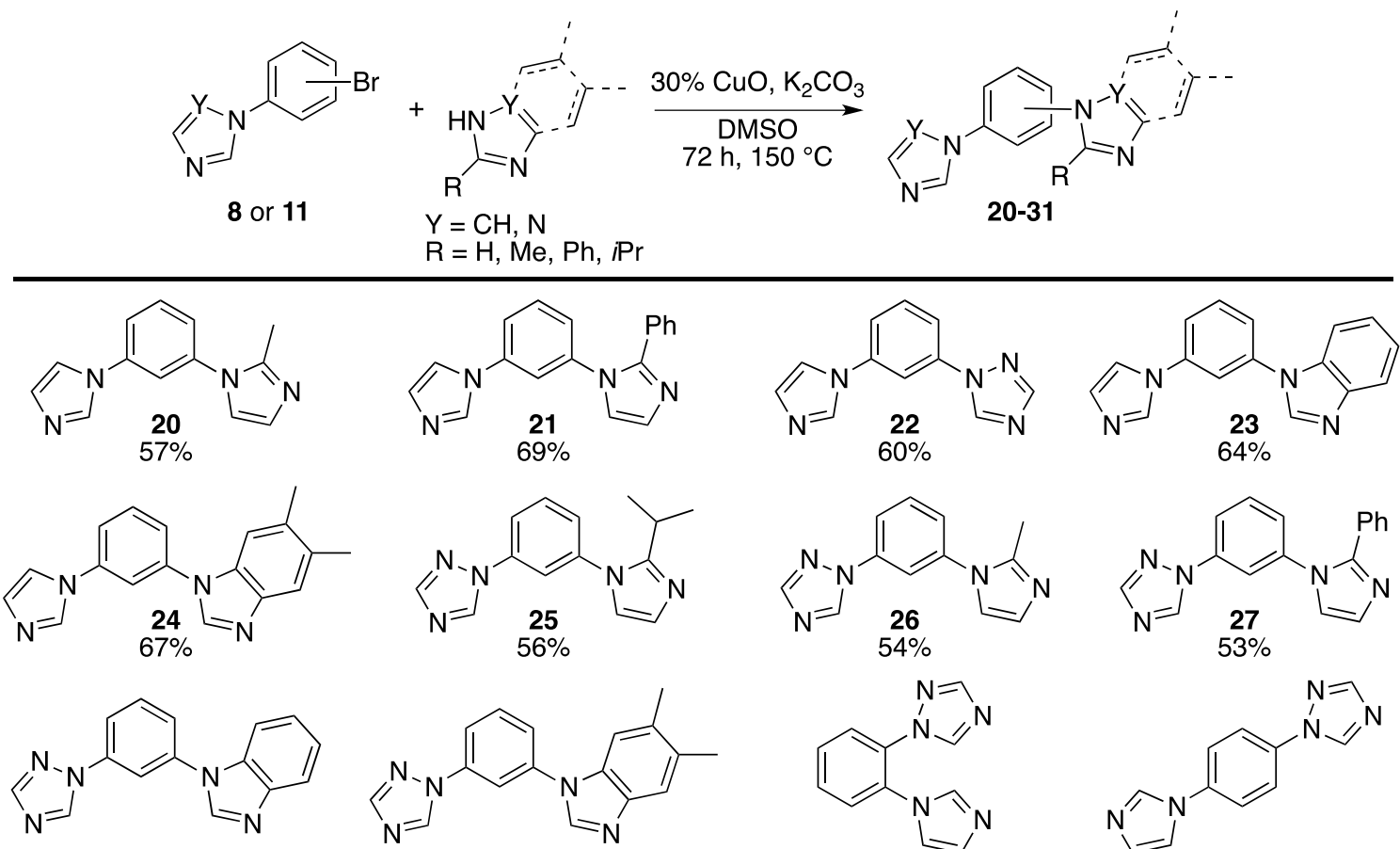<smiles>c1ccc(-n2cncn2)c(-n2ccnc2)c1</smiles>

28
$64 \%$

29
$59 \%$

30
$49 \%$<smiles>c1cn(-c2ccc(-n3cncn3)cc2)cn1</smiles>

X-ray quality crystals of compounds $\mathbf{2 0}$ were obtained by slow vapor diffusion of $\mathrm{Et}_{2} \mathrm{O}$ into a $\mathrm{CH}_{2} \mathrm{Cl}_{2}$ solution. An ORTEP illustration of the molecular structure of compound $\mathbf{2 0}$ was shown in Figure 2. In the absence of a transition metal, the structure is C1 symmetric. The C-2 substituted heterocyclic substituent was twisted out of the plane of the phenylene bridge (20: C1-C2-N3-C11, 56.72(13) $)$ in the opposite direction of the unsubstituted imidazole substituent. This twist was due to the steric bulk of the methyl substituent at C-2. The crystal of $\mathbf{2 0}$ was found to be in a chiral space group $\left(\mathrm{P} 2{ }_{1} 2_{1} 2_{1}\right)$ and contains only one enantiomer in the single crystal by spontaneous chiral resolution. Presumably the mixture contains an equal number of the alternate enantiomer. 
Figure 2. X-ray molecular structure of 20. Hydrogen atoms are omitted for clarity. Thermal ellipsoids are shown at $50 \%$ probability.

The final step in the synthesis of these unsymmetrical precursors was the alkylation to give bis(azolium) salts (Scheme 4). At a $1 \mathrm{~g}$ scale, all salts were isolated in high yield. As mentioned before, one compound (21) was reacted with several butyl halides $(\mathrm{Cl}, \mathrm{Br}, \mathrm{I})$ to give 33-35 with varying halogen counter ions. While all of the halide salts of $\mathbf{2 1}$ were isolated in high yield, the iodide salt provided a $95 \%$ yield in $16 \mathrm{~h}$ whereas the bromide and chloride salts required longer reaction times and higher temperatures. The isolation of the iodide derivative was also much easier than that of the bromide and chloride due to its tendency to precipitate out of the reaction mixture. All iodide salts were isolated as light yellow crystalline solids, which are of sufficient quality for further elaboration. If removal of any remaining iodine was necessary, the solid was dissolved in $\mathrm{CH}_{2} \mathrm{Cl}_{2}$ and washed with a saturated aqueous solution of sodium thiosulfate to obtain a white solid with minimal loss in yield. 
Scheme 4. Synthesis of unsymmetrical bis(azolium) salts.

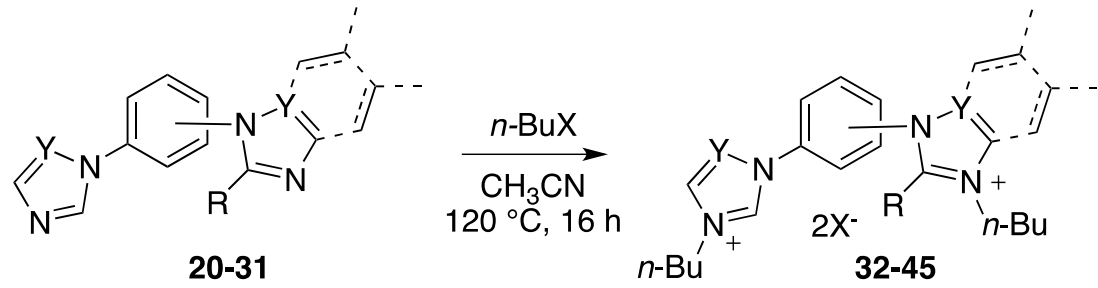

$\mathrm{Y}=\mathrm{CH}, \mathrm{N}$

20-31

32-45

$\mathrm{R}=\mathrm{H}, \mathrm{Me}, \mathrm{Ph}, \mathrm{Pr}$
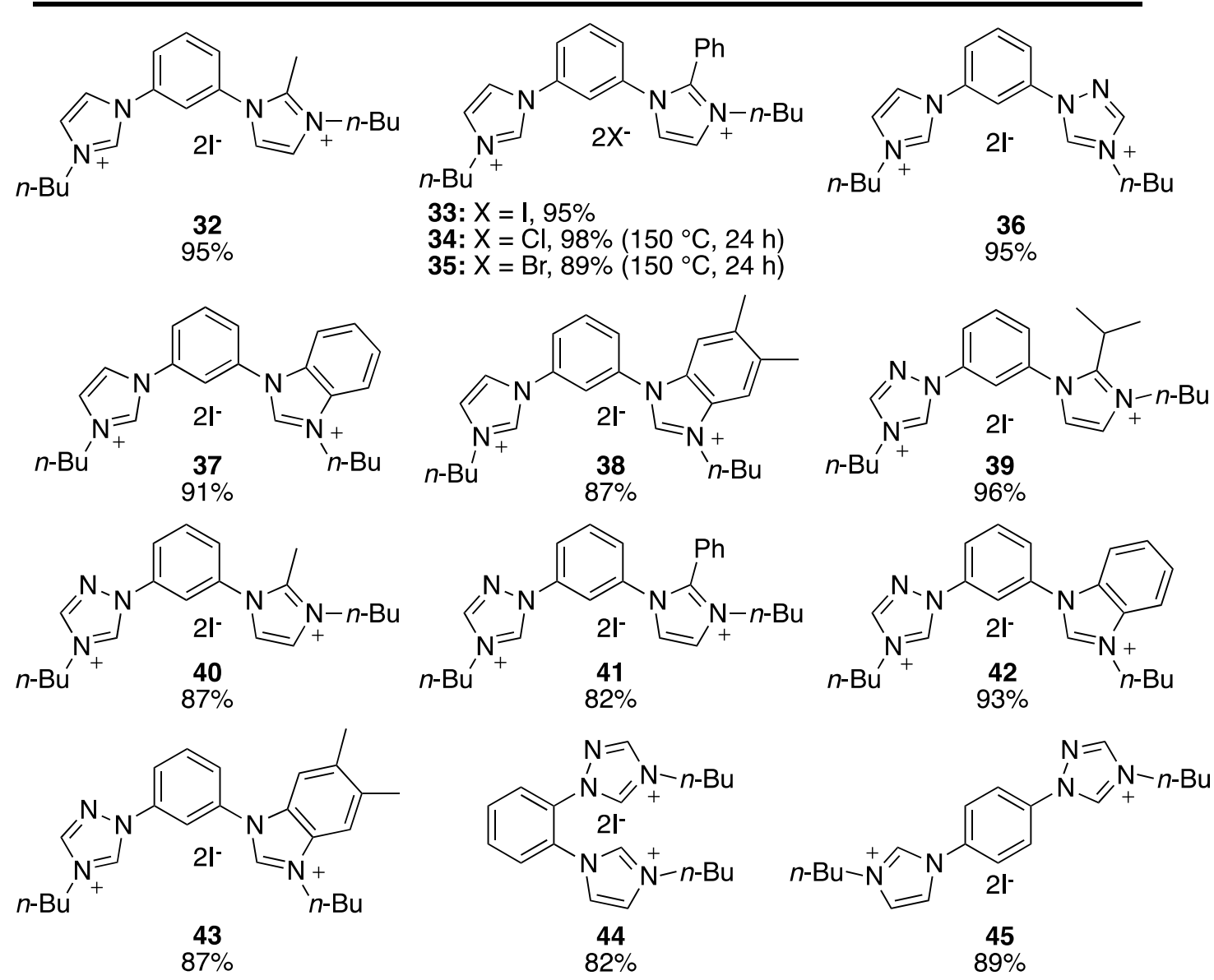

X-ray quality crystals of compound $\mathbf{3 7}$ were obtained by slow vapor diffusion of $\mathrm{Et}_{2} \mathrm{O}$ into a $\mathrm{CH}_{2} \mathrm{Cl}_{2}$ solution. The ORTEP diagram in Figure 4 shows the salt twisted, minimizing the steric interactions between arene and the heterocycles. The benzimidazolium donor group was twisted out of the plane of the phenylene bridge (C1-C6-N3-C10, 40.8(2) $)^{\circ}$ and in opposite direction from the imidazolium donor group (C1-C2-N1-C8, -33.2(3) ${ }^{\circ}$ ). 


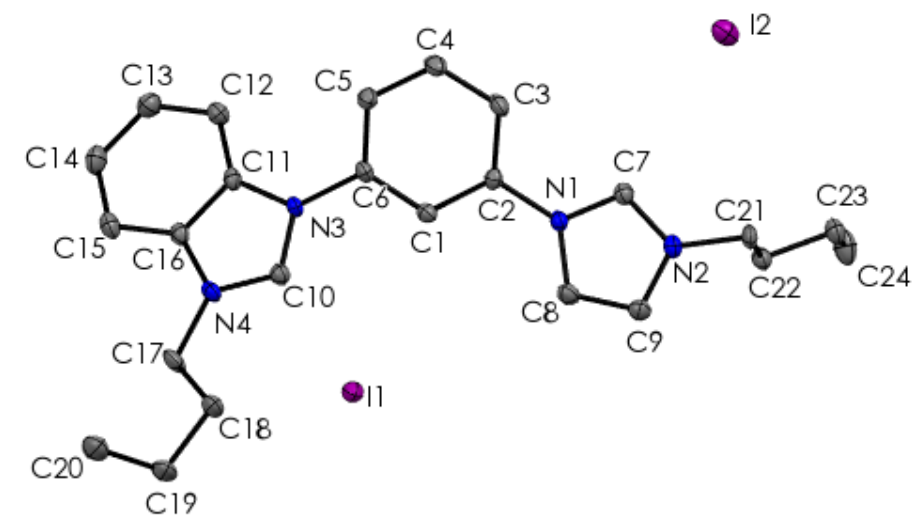

Figure 4. X-ray molecular structure of 37. Hydrogen atoms are omitted for clarity. Thermal ellipsoids are shown at $50 \%$ probability.

\section{Conclusions}

The reported methodology efficiently yielded unsymmetrical bis(azolium) salts in only three isolation steps. Furthermore, it has been shown that this methodology was not limited to imidazolium systems, but was applicable to triazolium and benzimidazolium systems. This method will allow for greater diversity in the design of transition metal ligands, antibacterial agents, ionic liquids, and many other systems exploiting azolium salts.

\section{Acknowledgements}

The National Science Foundation (OIA-1539035) and Mississippi State University Department of Chemistry and the Office of Research and Economic Development and are gratefully acknowledged for financial support. H.K.B. also acknowledges the Department of Education (GAANN-P200A120066) for fellowship support. 


\section{Supporting Information}

Full experimental details, characterization data and selected spectral data for all new compounds. CIF files for 20 (CCDC\# 1501474), and 37 (CCDC\# 1501475) are available or may be accessed at Cambridge Crystallographic Data Centre.

\section{References}

(1) Dua, R.; Shrivastava, S.; Sonwane, S. K.; Srivastava, S. K. Adv. Bio. Res. 2011, 5, 120.

(2) (a) D'Anna, F.; Nimal Gunaratne, H. Q.; Lazzara, G.; Noto, R.; Rizzo, C.; Seddon, K. R. Org. Biomol. Chem. 2013, 11, 5836; (b) Hillesheim, P. C.; Singh, J. A.; Mahurin, S. M.; Fulvio, P. F.; Oyola, Y.; Zhu, X.; Jiang, D.-e.; Dai, S. RSC Adv. 2013, 3, 3981; (c) Malhotra, S. V.; Kumar, V.; Velez, C.; Zayas, B. MedChemComm 2014, 5, 1404; (d) Martínez-Guerrero, L. J.; Wright, S. H. J. Pharmacol. Exp. Ther. 2013, 346, 495; (e) Meyer, D.; Strassner, T. J. Org. Chem. 2010, 76, 305; (f) Zheng, D.; Dong, L.; Huang, W.; Wu, X.; Nie, N. Renew. Sustainable Energy Rev. 2014, 37, 47.

(3) Teyssot, M.-L.; Jarrousse, A.-S.; Manin, M.; Chevry, A.; Roche, S.; Norre, F.; Beaudoin, C.; Morel, L.; Boyer, D.; Mahiou, R.; Gautier, A. Dalton Trans. 2009, 6894.

(4) Luo, Y.; Lu, Y.-H.; Gan, L.-L.; Zhou, C.-H.; Wu, J.; Geng, R.-X.; Zhang, Y.-Y. Arch. Pharm. Chem. Life Sci. 2009, 342, 386.

(5) (a) Demberelnyamba, D.; Kim, K.-S.; Choi, S.; Park, S.-Y.; Lee, H.; Kim, C.-J.; Yoo, I.-D. Bioorg. Med. Chem. Lett. 2004, 12, 853; (b) Hindi, K. M.; Panzner, M. J.; Tessier, C. A.; Cannon, C. L.; Youngs, W. J. Chem. Rev. 2009, 109, 3859; (c) Pernak, J.; Sobaszkiewicz, K.; Mirska, I. Green Chem. 2003, 5, 52.

(6) Crandall, I. E.; Zhao, B.; Vlahakis, J. Z.; Szarek, W. A. Bioorg. Med. Chem. Lett. 2013, 23, 1522.

(7) Gao, Y. V., J. Z.; Szarek, W. A.; Brockhausen, I. Bioorg. Med. Chem. 2013, 21, 1305.

(8) Yoon, J.; Kim, S. K.; Singh, N. J.; Kim, K. S. Chem. Soc. Rev. 2006, 35, 355.

(9) (a) Sajoto, T.; Djurovich, P. I.; Tamayo, A.; Yousufuddin, M.; Bau, R.; Thompson, M. E.; Holmes, R. J.; Forrest, S. R. Inorg. Chem. 2005, 44, 7992; (b) Son, S. U.; Park, K. H.; Lee, Y.-S.; Kim, B. Y.; Choi, C. H.; Lah, M. S.; Jang, Y. H.; Jang, D.-J.; Chung, Y. K. Inorg. Chem. 2004, 43, 6896; (c) Unger, Y.; Zeller, A.; Ahrens, S.; Strassner, T. Chem. Comm. 2008, 3263.

(10) (a) Chianese, A. R.; Li, X.; Janzen, M. C.; Faller, J. W.; Crabtree, R. H. Organometallics 2003, 22, 1663; (b) Danopoulos, A. A.; Pugh, D.; Smith, H.; Saßmannshausen, J. Chem. Eur. J. 2009, 15, 5491; (c) Díez-González, S.; Marion, N.; Nolan, S. P. Chem. Rev. 2009, 109, 3612; (d) Kantchev, E. A. B.; O'Brien, C. J.; Organ, M. G. Angew. Chem., Int. Ed. 2007, 46, 2768; (e) Peris, E.; Crabtree, R. H. Coord. Chem. Rev. 2004, 248, 2239.

(11) Bourissou, D.; Guerret, O.; Gabbaï, F. P.; Bertrand, G. Chem. Rev. 2000, 100, 39.

(12) (a) Aldeco-Perez, E.; Rosenthal, A. J.; Donnadieu, B.; Parameswaran, P.; Frenking, G.; Bertrand, G. Science 2009, 326, 556; (b) Arduengo, A. J.; Harlow, R. L.; Kline, M. J. Am. Chem. Soc. 1991, 113, 361.

(13) Bertrand, G. Carbene Chemistry: From Fleeting Intermediates to Powerful Reagents; Taylor \& Francis, 2002. 
(14) (a) Bourissou, D.; Guerret, O.; Gabbai, F. P.; Bertrand, G. Chem. Rev. 2000, 100, 39; (b) Vignolle, J.; Cattoën, X.; Bourissou, D. Chem. Rev. 2009, 109, 3333; (c) Schuster, O.; Yang, L.; Raubenheimer, H. G.; Albrecht, M. Chem. Rev. 2009, 109, 3445; (d) Mizuhata, Y.; Sasamori, T.; Tokitoh, N. Chem. Rev. 2009, 109, 3479.

(15) Zuo, W.; Braunstein, P. Dalton Trans. 2012, 41, 636.

(16) (a) Clark, W. D.; Tyson, G. E.; Hollis, T. K.; Valle, H. U.; Valente, E. J.; Oliver, A. G.; Dukes, M. P. Dalton Trans. 2013, 42, 7338; (b) Vargas, V. C.; Rubio, R. J.; Hollis, T. K.; Salcido, M. E. Org. Lett. 2003, 4847. 


\section{Graphical Abstract}

An Efficient Route to Unsymmetrical Bis(azolium) Salts: CCC-NHC Pincer Ligand Complex Precursors

Hannah K. Box, Tyler O. Howell, William E. Kennon, Griffin A. Burk, Henry U. Valle, T. Keith Hollis* Department of Chemistry, Mississippi State University, MS State, Mississippi 39762

khollis@chemistry.msstate.edu

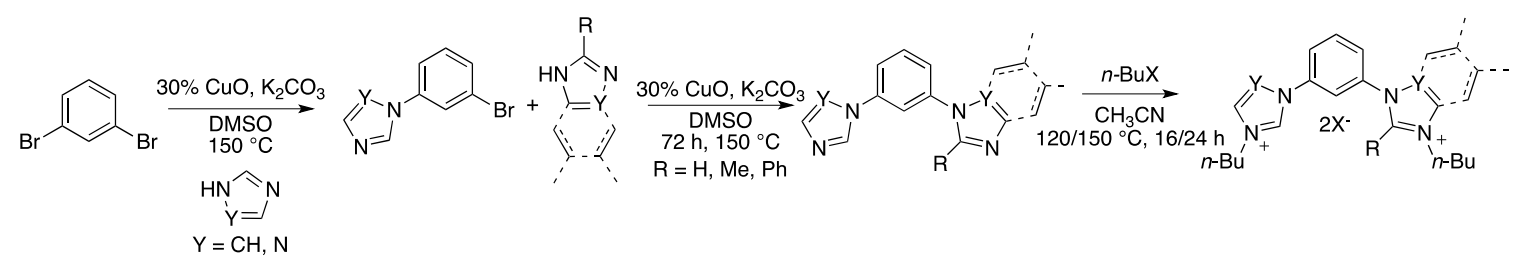

